\title{
Teachers' Understanding of Biodiversity, Conservation, and Hotspots Biodiversity Concepts
}

\author{
Hasna Nuraeni \\ Student of Postgraduate School of Science Education \\ Program - Indonesia University of Education (UPI) and \\ Science Teacher on Junior High School 4.Lembang \\ Bandung, Indonesia \\ hasnalembang@yahoo.com
}

\author{
Nuryani Y. Rustaman \\ Lecturer of Postgraduate School of Science Education \\ Program - Indonesia University of Education \\ Bandung, Indonesia \\ nuryani_rustaman@yahoo.com
}

\author{
Topik Hidayat \\ Lecturer of Postgraduate School of Science Education Program \\ Indonesia University of Education \\ Bandung, Indonesia \\ topikhidayat@upi.edu
}

\begin{abstract}
One of the main problems of the global environment is the crisis of biodiversity loss. The ability of teachers was instrumental in the successful implementation of biodiversity and conservation education so as to produce citizens who are concerned and responsible. Depth questionnaire survey, aims to explore the capabilities of teachers' understanding of the concept of biodiversity, conservation, and biodiversity hotspots. Some 21 science teachers from various districts in the province of West Java and Banten involved in this research. The results showed in general teachers do not holistically understand the concept of biodiversity and conservation. Even the concept of biodiversity hotspots are generally not recognized by the teacher. The ability of teachers to update their knowledge and limitations on resource book to be the cause of the weakness . Teachers are expected to update their knowledge through various ways and to optimize the resources available. Development resource book for teachers in order to improve holistic knowledge about biodiversity and conservation has also become a necessity.
\end{abstract}

Keywords-biodiversity; conservation; biodiversity hotspots

\section{INTRODUCTION}

The OECD Environmental Outlook 2030 identified some problems that the main challenge for the global environment that includes climate change, the crisis of biodiversity loss, water supply and sanitation, as well as a decrease in the health effects of environmental degradation [18]. The loss of biodiversity is one of global environmental issues most pressing of our time [15];[20];[25]. One of the efforts undertaken by the global community is the introduction of environmental education for all walks of life and all levels of education, both formal and informal [24].

The main objective of environmental education is to give everyone the opportunity to acquire the knowledge, values, attitudes, commitment and skills needed to protect and improve the environment [24].Taking into account the goals ofenvironmental education, no other now known as the environment literacy. The same basic purpose can also be set for biodiversity education is perceived to be a bridge between environmental education and biodiversity conservation education [6];[26];[27].Therefore, the purpose of biodiversity education is biodiversity literacy.

Biodiversity education is essential if conservation approach is successfully implemented as public support and awareness is critical to the conservation of nature [4];[23];[25]. Teachers' understanding about biodiversity and its loss should be considered for the successful implementation of biodiversity education in schools [3];[13].

Biodiversity is defined by the Convention on Biodiversity as the variability among living organisms from all sources including, inter alia, terrestrial, marine and other aquatic ecosystems and the ecological complexes of them are part: this includes diversity within species, between species and of ecosystems [25]. In short, biodiversity occurs at three levels of different organizations: (1) genetic diversity, (2) diversity of species, and (3) diversity of ecosystems [5];[10]. Each component of the biodiversity of both of genes, species, and ecosystems provide society with various goods and services. Therefore, biodiversity is essential for human beings.

Due to human activities, such as habitat fragmentation and changes, the introduction of invasive alien species, harvesting, over exploitation, pollution, loss of biodiversity at all levels of the organization to rise at an alarming rate [16];[20]. This can lead to higher food insecurity, increasing vulnerability of ecosystems, and the deteriorating health of human and social relationships [16]. On a global scale, not only the location but also the threat to biodiversity is not evenly distributed. Therefore, the priority conservation areas are crucial to minimize the loss of biodiversity [1]. Template best conservation is established to promote the concept of biodiversity hotspots, which represents a reservoir of biodiversity richest and most threatened on Earth [1];[17].In addition, the concept of biodiversity hotspots have become an integral part of many educational materials for students 
[19];[21]. If conservation measures are not immediately taken in biodiversity hotspots, many of the world's biodiversity will be lost [1];[17].

Meaning conservation holistically by Western and Pearl [11] covering the three principles, namely the approach to save, study and use. According Supriatna [11] three of these principles is a holistic approach that is expected to protect the species by not leaving the beneficial aspects. The understanding of conservation is not holistic led to the conservation still fail [11]. Therefore, Rifai [11] suggest the need to change the mind set approach in conservation efforts by promoting sustainable use.

A teacher has the potential to affect many students throughout his career, and the university has the potential to affect many future teachers and, ultimately, a much larger number of students [9];[12];[13]. Because of the close relationship between the topic of biodiversity and the subject of ecology, biology teachers have an important role in the education of biodiversity [7]. The understanding of terminology, global dimension, and the complex interactions between ecological factors and socio-economic causes of biodiversity loss is a challenging concept, even for science teachers [7];[22].Teachers' competence adequate will affect the success of biodiversity education.

Teachers'competencies are believed as one of the factors that determine the success of biodiversity education. Nevertheless, according to some research, there are problems on teachers or student teachers of science associated with biodiversity. Poll 'Biodiversity in the Next Millennium', conducted by the American Museum of Natural History, revealed that only $38 \%$ describe the student teachers are very familiar with the concept of biodiversity "[3]. The majority of students feel unfamiliar with biodiversity, and consequently not competent enough to teach biodiversity issues in schools [12]; [13]. Most of other studies reveal prospective biology teachers have problems in understanding the full meaning of biodiversity [22];[13]. An in-depth interview in the study of biodiversity issues with in-service elementary school teacher in the UK revealed that biodiversity, especially in terms of species, whereas genetic diversity is poorly understood and explained only in terms of simple genetic. Dikmenli [2] did a word association test of biodiversity on the biology teachers in Turkey. These authors found that participants think of biodiversity, especially as the diversity of ecosystems, followed by associations connected with the diversity of species, and the genetic diversity mainly ignored [2]. Fiebelkorn \& Menzel [3] found that prospective teachers of German and Costa Rica equate biodiversity with species diversity and have misconceptions about genetic diversity. The same trend was found in student teachers in Banten Indonesia [11]. The researchers found that most prospective teachers have not understanding of the holistic concept of biodiversity and conservation. Although most of the participants are not familiar with the scientific concept of biodiversity hotspots, they implicitly use the concept of biodiversity naive to explain the distribution and global biodiversity loss [14].
Indonesia is a country with mega biodiversity, which is characterized by a diversity of ecosystems, species, and germplasm (genetic) that are within each type. If the statistics relating to the number of types multifaceted, Indonesia always tops the list [8]. Accordingly, Indonesia has one of the mega biodiversity states of the world. Indonesia is also a country with a high level of threatened environmental, especially the extinction of species and habitat destruction, which led to loss of biodiversity. Therefore, Indonesia has also become one of the main global biodiversity hotspots. West Java is one of the provinces in Indonesia which is rich in biodiversity. This province also experienced a very rapid development. Indeed, this has become a pride for the community but on the other side has potentially the highest biodiversity crisis too. This happens because of the high population and human activities that lead to biodiversity loss. Therefore, efforts should be made to promote the conservation of biodiversity through education at all levels. The success of the study of biodiversity in the province determines the preservation of the future of biodiversity. As the spearhead of education, the ability of science teachers determine the educational success of biodiversity and conservation characterized by increased literacy biodiversity. One of the components of literacy biodiversity is the realm of content knowledge of biodiversity which includes knowledge of concepts key of biodiversity, problems and issues related to biodiversity, as well as knowledge of the rescue biodiversity strategies and action [29]. The ability of adequate teachers in understanding the key concepts of biodiversity, conservation, and biodiversity hotspots needed so that they can teach biodiversity properly to the students. A correct understanding of these concepts form the basis for coached literacy biodiversity, namely the ownership of the knowledge, skills, attitude, and action, so they can solve problems in everyday life related to biodiversity.

Based on the above, the main purpose of this study was to explore the science teachers' understanding of the concept of biodiversity, conservation, and biodiversity hotspots. Knowledge of the ability of teachers to understand the key concepts related to biodiversity is required as a basis to improve the educational success of biodiversity. Increasing the success of biodiversity education can be done through increasing literacy biodiversity among teachers that will ultimately have an impact on students' literacy biodiversity.

\section{METHOD}

In order to achieve the purpose of research, we chose a qualitative method, through in-depth survey approach. A total of 21 junior high school science teachers from several districts in West Java province ( $\mathrm{n}=21$, years of service $=1-30$ years $)$ in 2015 have participated in this study. A number of questions in the questionnaire about the concept of biodiversity, conservation, and biodiversity hotspots provided to the respondent . To strengthen and complement the answers on the questionnaire, participants were also asked to make a sketch showing their understanding of the concept of biodiversity.To complement and reinforce answers regarding the concept of biodiversity hotspots, they were asked to complete a world map that shows regions that have high biodiversity and threatened. Areas that have high biodiversity 
are marked green, while the threatened area marked in red. Kress and van Leeuwen [3] clicking assume that individual representation of the concept through words and images are comparable. Goodman [3] states that using this logic, the picture can be seen as a representation of symbol systems such artificial languages. We concluded that the image can be analyzed on the basis of the same theory as representations verbally. To complete answers regarding the conservation concept, participants were asked to write down examples of activities that demonstrate their understanding of the concept of biodiversity conservation.

Overall the data were analyzed, classified, percentages are calculated, and then interpreted qualitatively. Answer our respondents are classified into: (1) do not understand; (2) understand not holistically; (3) understand holistically. Once data was classified percentages and calculated. The results were interpreted according to the following criteria.

TABLE I. CATEGORY ACHIEVEMENT LEVEL OF UNDERSTANDING

\begin{tabular}{|l|l|}
\hline \multicolumn{1}{|c|}{ Achievement score } & \multicolumn{1}{c|}{ Category Achievement } \\
\hline $100 \%$ & Wholly \\
\hline $76 \%-99 \%$ & In general \\
\hline $51 \%-75 \%$ & Most of the \\
\hline $50 \%$ & Half \\
\hline $26 \%-49 \%$ & Nearly half \\
\hline $1 \%-25 \%$ & Fraction \\
\hline
\end{tabular}

\section{RESULT}

\section{A. Understanding of Biodiversity Concept}

Biodiversity is not only synonymous with the diversity of species. Biodiversity is the variability found in three levels of genes, species and ecosystems [5];[10];[26]. The uunderstanding of the concept of biodiversity science teacher is shown in Figure 1.

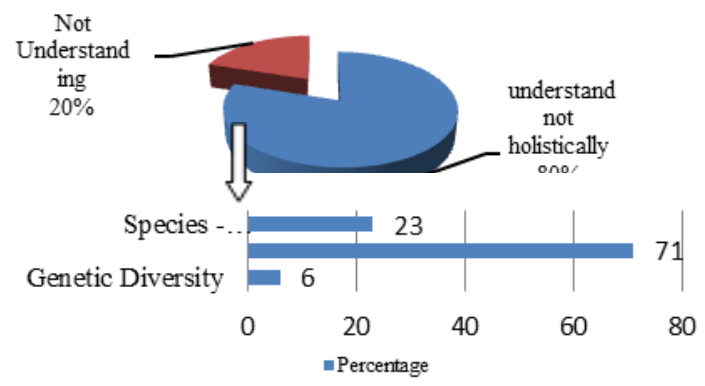

Fig. 1. Science Teachers' Understanding of Biodiversity Concept

The data in Figure 1 shows that in general of science teachers do not understand the concept of biodiversity holistically; even a small percentage did not understand the concept. Science teachers who do not understand the concept of biodiversity holistically, the majority $(71 \%)$ understand that biodiversity just as species diversity. These finding illustrate that in general, science teachers have misconceptions about the concept of biodiversity.

\section{B. Understanding of Conservation Concept}

Meaning conservation holistically by Western and Pearl [11] covering the three principles, namely the save, study and use. According Supriatna [11] three principles of holistic, it is expected to protect the species by not leaving the beneficial aspects.The understanding of science teachers about conservation are shown in Figure 2.

The data in Figure 2 shows in general of teachers who do not have a holistic understanding of the concept of conservation, there's even $10 \%$ who do not understand at all. Teachers who do not understand holistically about conservation significance, in general interpreted the concept of conservation as protection only, which means that living beings should be protected and should not be used.

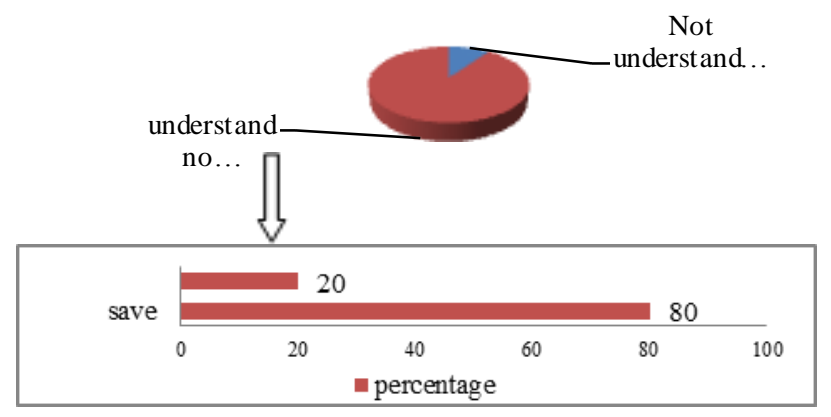

Fig. 2. Science Teachers' Understanding of Conservation Concept

Such views show paradigm that is not appropriate because the meaning conservation areprotection, research and sustainable use. Leksono [11] states that this view led to the conservation still failed to do.

\section{Understanding of Biodiversity Hotspots}

In addition to the importance of the concept of biodiversity and conservation, the research also explored the concept of biodiversity hotspots and the existence of Indonesia as part of a global biodiversity hotspot. Biodiversity hotspots are areas that have the highest level of biodiversity as well as areas that have a high level of threatened [17]. The results of the study are shown in Figure 3.

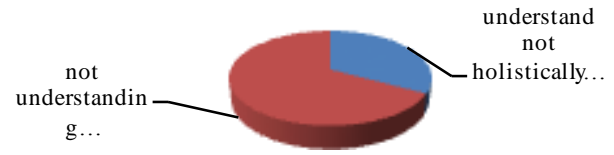

Fig. 3. Science Teachers' Understanding of Hotspots Biodiversity Concept

\section{DISCUSSION}

The results showed that science teachers have a weakness in understanding the concept of biodiversity, conservation and biodiversity hotpots, and did not know that Indonesia is one of the world's biodiversity hotspots. The weakness of this teacher in all ages was associated with the ability to update their knowledge through the resources that are currently available. Figure 4 shows the utilization of resources by teachers in studying the concept of biodiversity and conservation.

Figure 4 shows that the utilization of resources to understand the concept of biodiversity and conservation by teachers mostly through school she ever experienced in high school and college. In fact, when seen from the teaching experience of teachers have been teaching for 1-30 years. This may imply the teacher is not able to update their knowledge. 
The ability of teachers to renew their knowledge is absolutely necessary that he have adequate competence of literacy biodiversity for further teaching to the students.

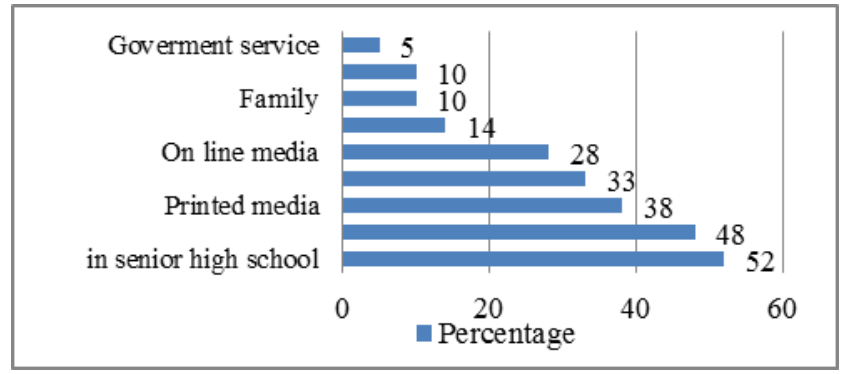

Fig. 4. Teachers' Utilization of Sources Information about Biodiversity and Its Conservation

Figure 4 also shows that the roles of the print media, electronic media, online media, environmental organizations, family, friends, and government services have not been widely used by teachers. This contrasts with the results of research Lindemann [13] which states that the family, friends, government services, and environmental organizations play a source of information related to the conservation of biodiversity for prospective teachers in Germany, Cyprus, the UK, and Sweden. This occurs because although countries have a wealth of biodiversity is not as rich as in Indonesia, but most citizens concerned about the environment.

As one of the world's biodiversity hotspots and megabiodiversity country, every citizen should be concerned about this and is responsible for its preservation. Science teachers play an important role in shaping a concerned citizen and environmentally responsible. Therefore, teachers must always update their knowledge through various ways and optimize the learning resources available. Associated with the use of print media such as books, through in-depth interviews and questionnaires obtained information that the source books used by teachers in general is still limited to textbooks that have not loaded the concept of biodiversity and conservation in a holistic manner. Book resources currently available are also not provided information on the concept of biodiversity hotspots. It is also not entered insight into global issues and local related to biodiversity and conservation. Therefore it takes a guidebook for teachers who can provide a greater insight to teachers about biodiversity and conservation education.

Limitation of this study is that the results can not be generalized because of the lack of a representative sample of West Java Province. However, this study has provided insight about attainment of understanding of related biodiversity concepts in West Java science teacher.

\section{CONCLUSION AND EDUCATIONAL IMPLICATION}

Based on the results of this study concluded that science teacher in this case generally have no holistic understanding of the concept of biodiversity and conservation. In addition, the biodiversity hotspots in the foreign general science teachers. Therefore, science teachers are encouraged to continue to update their knowledge through the use of various sources of knowledge available. Moreover it is essential to develop a resource book for teachers to provide a holistic knowledge about biodiversity and conservation education.

\section{Acknowledgment}

The authors would particularly like to thank all the science teachers for their time and effort in participating in the study.

\section{References}

[1] Brooks, T.M.,Mittermeier, R. A., da Fonseca, G. A. B., Gerlach, J., Hoffmann, M., Lamoreux, J. F.,Mittermeier, C. G., et al. (2006). Globalbiodiversity conservation priorities. Science, 313(58), 58-61.

[2] Dikmenli, M. (2010).Biology studentteachers' conceptual frameworks regarding biodiversity. Education, 130(3), 479-488.

[3] Fiebelkorn,F., Menzel, S.(2013). Student Teachers' Understanding of the Terminology, Distribution, and Loss of Biodiversity: Perspectives from a Biodiversity Hotspot and an Industrialized Country. Res Sci Educ, 43(4), 1593-1615.

[4] Fischer, A.\& Young, J. C. (2007). Understanding mental constructs of biodiversity: implications for biodiversity management and conservation. Biological Conservation, 136(2), 271-282.

[5] Gaston, K. J. (2000). Global patterns in biodiversity.Nature, 405(6783), 220-227.

[6] Gayford, C. (2000). Biodiversity education: a teacher's perspective. Environmental Education Research, 6(4), 347-361.

[7] Gayford, C. (2001). Biodiversity reduction as a vehicle for exploring teacher thinking about issues in biological education. Retrieved from http://intl.concord.org/cbe/pdf/gayford.pdf. Accessed 20 Oct 2010.

[8] Junior. (2012). Megadiversitas Indonesia. Online. http://mallojunior.blogspot.co.id/2012/10/megadiversitas-indonesia.html

[9] Kassas, M. (2002). Environmental education: Bbiodiversity. The Environmentalist, 22(4), 345-351.

[10] Laveque, C.\& Mounolou, J.C. (2004). Biodiversity. West Sussex: John Willey \& Sons, Ltd.

[11] Leksono, S.M. (2014). Conservation Biology Learning Program Based Local Wisdom for Developing Literacy Biodiversity for prospective Biology Teacher. (Dissertation, un published). Graduate School, Universitas Pendidikan Indonesia, Bandung.

[12] indemann-Matthies, P., Constantinou, C., Junge, X., Köhler, K., Mayer, J., Nagel, U., \&Raper, G., (2009). The integration of biodiversity education in the initial education of primary school teachers: four comparative case studies from Europe. Environmental Education Research, 15(1), 17-37.

[13] Lindemann-Matthies, P., Constantinou, C., Lehnert, H.-J., Nagel, U., Raper, G.\& Kadji-Beltran, C. (2011). Confidence and perceived competence of preserve teachers to implement biodiversity education in primary schools - four comparative case studies from Europe. International Journal of Science Education, 33(16), 2247-2273.

[14] Menzel, S.\& Bögeholz, S. (2008). The loss of biodiversity as a challenge for sustainable development: how do pupils in Chile and Germany perceive resource dilemmas? Research in Science Education, 39(4), 429-447.

[15] Menzel \& Bogeholz, 2010. Values, beliefs and Norms that foster Chilean and German Pupils' Commitment to Protect Biodiversity. International Journal of Environmental \& Science Education, .5(1), 3149.

[16] MEA (Millennium Ecosystem Assessment). (2005). Ecosystems and human well-being: biodiversity synthesis. Washington, DC: World Resources Institute. Retrieved from http://www.maweb.org/documents/document.354.aspx.pdf. Accessed 20 Oct 2010.

[17] Mittermeier, R. A., Robles Gil, P., Hoffmann, M., Pilgrim, J., Brooks, T., Mittermeier, C. G., \&Lamoreux, J. (2004). Hotspots revisited: Earth's biologically richest and most endangered terrestrial Eco regions. Mexico City: CEMEX. 
[18] OECD. (2008). the OECD Environmental Outlook to 2030. Paris: OECD.

[19] Schack, K., Schreier, A., \& Richter, F. J. (Eds.), (2008). Biological diversity: Eeducational and information materials (p. 96). Berlin: BMU.

[20] Secretariat of the Convention on Biological Diversity. (2010). Global biodiversity outlook 3. Montréal, Canada: Secretariat of the Convention on Biological Diversity.

[21] Sigl, W. (2011). Hotspots der Biodiversität - Krisenregionen der Natur [Biodiversity hotspots - crisis regions of nature]. FWU Institute für Film und Bild: Ernst Klett.

[22] Summers, M., Corney, G., \& Childs, A. (2004). Student teachers' conceptions of sustainable development: The starting-points of geographers and scientists. Educational Research, 46(2), 163-182.

[23] Trombulak, S. C., Omland, K. S., Robinson, J. A., Lusk, J. J.,Fleischner, T. L., Brown, G., \& Domroese, M. (2004). Principles of conservation biology: recommended guidelines for conservation literacy from the Education Committee of the Society for Conservation Biology. Conservation Biology, 18(5), 1180-1190.

[24] UNESCO (1978). Intergovernmental Conference on Environmental Education, Tbilisi (USSR), 14-26 October 1977: Final Report. October (p. 96), Paris. Retrieved from http://www.gdrc.org/uem/ee/EETbilisi_1977.pdf. Accessed 20 Oct 2010.

[25] UNCED (United Nations Conference on Environment and Development). (1992). Convention on Biological Diversity (CBD) (p. 30). Rio de Janeiro: United Nations Conference on Environment and Development.

[26] van Weelie, D., \& Wals, A. E. J. (2002). Making biodiversity meaningful through environmental education. International Journal of Science Education, 24(11), 1143-1156.

[27] Working Group on Biological Diversity (Ed.) (2011). Biological diversity and education for sustainable development - key topics and starting points for educational programms. Bonn, Germany: German Commission for UNESCO.

[28] WWF \& Winconsin Center for Environmental Education, University of Winconsin. (1996). Report to the development of a biodiversity literacy assessment instrument. Wisconsin-Steven Point: National Education and Training Foundationn. 